\title{
PREVALENCE OF MASTITIS PATHOGENS AND THEIR RESISTANCE AGAINST ANTIMICROBIAL AGENTS IN AWASSI SHEEP IN AL-BALQA PROVINCE OF JORDAN
}

\author{
${ }^{1}$ Azmi D. Hawari, ${ }^{2}$ Maher Obeidat, ${ }^{3}$ Saddam Sh. Awaisheh, \\ ${ }^{4}$ Hala I. Al-Daghistani, ${ }^{5}$ Amal A. Al-Abbadi, ${ }^{3}$ Sharaf S. Omar, \\ ${ }^{5}$ Issam M. Qrunfleh, ${ }^{3}$ Hanee M. Al-Dmoor and ${ }^{3}$ Jafar El-Qudah \\ ${ }^{1}$ Faculty of Allied Medical Sciences, Arab American University, Jenin/Palestine \\ ${ }^{2}$ Department of Biotechnology, \\ ${ }^{3}$ Department of Nutrition and Food Processing, \\ ${ }^{4}$ Department of Medical Allied Sciences, Al-Salt College for Humanitarian Sciences, \\ ${ }^{5}$ Department of Plant Production and Protection Faculty of Agricultural Technology, \\ Al-Blaqa' Applied University, Al-Salt 19117, Jordan
}

Received 2014-03-14; Revised 2014-04-30; Accepted 2014-05-03

\begin{abstract}
The primary objective of this study was to establish data on mastitis in Awassi Sheep in Al-Balqa Province of Jordan. Milk samples were collected from 260 lactating ewes that selected randomly from eight flocks. California Mastitis Test (CMT) gave result with 220 milk samples; 122 samples (55.5\%) showed positive CMT. Infection with some bacterial species was associated with positive CMT. About $26 \%$ of the ewes revealed clinical signs of mastitis. The highest percentage of bacterial count, which range from $3 \times 10^{2}$ to $<3.0$ $10^{3} \mathrm{cfu} \mathrm{\textrm {mL } ^ { - 1 }}$ was founded in the milk samples. The most predominant bacteria isolated were Staphylococcus aureus, Streptococcus agalactiae, Streptococcus spp., Escherichia coli, Corynebacterium spp. and Coagulase negative Staphylococci. Sensitivity tests were applied to different isolated strains., Gentamycim, Ampicillin and Tetracycline were the most effective antimicrobial agents against the bacterial isolates.
\end{abstract}

Keywords: Awassi Sheep, Mastitis in Ewes, California Mastitis Test, Jordan

\section{INTRODUCTION}

Mastitis, similar to most livestock disease, is a result of the interaction between the host, pathogen and environment, although stress and physical injuries may cause inflammation of mammary gland, infection by invading bacteria or other microorganisms (fungi, yeast) is the primary cause of mastitis. It is the course of multiple hazardous effects on human health and animal production.

This inflammation of the mammary gland (mastitis) is known to be a complex and costly disease (Radostitis et al., 1994) The disease is associated with a decrease in milk production, an increase of veterinary services, treatment, labour costs and culling (Fthenakis, 1994). Mastitis is one of the most series economic and health problems of small Corresponding Author: Azmi D. Hawari, Faculty of Allied Medical Sciences, Arab American University, Jenin/Palestine ruminates flocks worldwide (Las Heras et al., 1999; Corrales et al., 2004; Osman et al., 2013). Current Knowledge of mastitis in small ruminants has been reviewed by some authors (Bergonier et al., 2003; Bergonier and Berthelot, 2003; Lafi et al., 1998; Contreras et al., 2007). The causative organisms of mastitis are categorized as major or minor pathogens (Harmon, 1994). The most common major pathogens include Staphylococcus aureus, Streptococcus agalaciae, Coliforms and Enterococci, while other pathogens such as Streptococcus spp., Pseudomonas aeruginosa, Mannheimia hemolytica, Corynebacteria, Coagalase negative Staphylococci and Fungi, are considered to be minor pathogens which can produce Intramammary Infection (IMI) in small ruminants, but occurance rates are 
lower (Contreras et al., 2007). In Asia bovine major mastitis causing organisms are Staphylococcus aureus, Streptococci, E. Coli., Corynebacterium spp and klebsiella spp., but recent reports indecating the changing trend from Staphylococcus aureus to Coagulase Negative Staphylococci (Sharma et al., 2012).

In North Greece, clinical mastitis of ovine was recorded in $11.4 \%$ of ewes examined. Mycoplasma spp. and Staphylococcus aureus were the important pathogens, as they were isolated from 45.9 and 38.5 percent respectively of mammary secretions samples, while other microorganism were isolated at a lower rate (Fthenakis and Jones, 1990). The annual incidence of clinical mastitis in small ruminants is generally lower they $5 \%$, but this incidence can increase sporadically (Contreras et al., 2007). The prevalence of subclinical mastitis has been estimated at $5-30 \%$ or even higher (Bergonier and Berthelot 2003; Contreras et al., 2003).

In Egypt coagulase-negative Staphylococci were isolated from the examined subclinical mastitic sheep and goats with percentages of 50 and $55.6 \%$ respectively (El-Jakee et al., 2013).

In Jordan there are about 2.4 million Awassi sheep. The good adaptability of this breed to semi-dry climate encouraged sheep farmers to raise this breed in Jordan. This breed is raised for meat, milk and wool production. As Jordan lacks reliable information concerning the approporiate treatment of mastitis and due to the unregulated use of veterinary drugs, the objective of this study to isolate and identify the major udder pathogens and to determine the incidence of clinical and subclinical mastitis in ewes, a further objective was to determine the susceptibility of these bacteria to 6 antimicrobial agents that are or have been commonly used in Jordan.

\section{MATERIALS AND METHODS}

This study was conducted during the year 2012 and 2013. Milk samples were collected from 260 lactating ewes that selected randomly from eight flocks in AlBalqa province. All udders were subjected to clinical examinations such as swelling and presence of lesions or anatomical malformation. Clinical mastitis was defined by the presence of abnormal udder secretions (clots, flakes, or abnormalities in color or consistency) and detection of mastitis pathogens by bacteriological culture, whereas subclinical mastitis was recognized by apparently normal milk and increase in leukocyte counts as evidenced by California Mastitis Test (CMT) and a positive culture result. CMT was used to give an indication of the number of somatic cells, it based upon a gelling reaction between the nucleic acid of the cells and a detergent reagent. The CMT was chosen in several investigation because it is more perfect, efficient and reliable than other field and chemical tests for diagnosis of subclinical mastitis (Dingwell et al., 2003; Sargeant et al., 2001; Sharma et al., 2011, Osman et al., 2013). CMT score 0 was taken as negative, while CMT socres trace, $1+, 2+$ and $3+$ were considered positive. All milk samples irrespective of CMT result was bacteriologically examined. For determination the total bacterial count, a volume of 0.1 $\mathrm{mL}$ of each milk sample was spread on Plate Count Agar (Oxoid); plates were incubated at $37^{\circ} \mathrm{C} 24 \mathrm{~h}$ and then developing colonies were counted. Direct streaking was done on duplicate 7\% sheep blood agar and Macconkey agar plates; plates were incubated aerobically and anaerobically using Gas Pack System at $37^{\circ} \mathrm{C}$ and examined after 24 and 48 h. Bacteriological examinations were carried out following standard methods (Quinn et al., 1994; Sears et al., 1993). Presumptive identification of bacterial isolated was made based on colony morphological features, Gram-stain reaction, hemolytic characteristic and a catalase test.

Staphylococci and Micrococci were identified based on their growth characteristics on mannitol salt agar, coagulase production, catalase and oxidase test. Streptococci were evaluated according to CAMP reaction, growth characteristics on Edward's medium, hydrolysis of esculin, sodium hippurate, catalase production and sugar fermentation tests. Gram-negative isolates were subcultured on MacConkey agar and further tested using Triple Sugar Iron (TSI) agar (Oxoid), the IMVIC test (indol, methyl red, Voges-Proskuer and citrate utilizing test), urea, lysine and ornithine decarboxylase and oxidase reactions.

Sensitivity tests were carried out by using MullerHinton Agar (oxoid) and susceptibility discs (oxoid) to test the susceptibility of the isolates to some antibiotics, $10 \mu \mathrm{g}$ Ampicillin, $10 \mu \mathrm{g}$ Gentamycin, 10 IU Penicillin, $30 \mu \mathrm{g}$ Tetracycline, $30 \mu \mathrm{g}$ Neomycin and $25 \mu \mathrm{g}$ Sulfamethoxazole.

All statistical analyses were performed using SAS/STAT Version 9.2 SAS (Institute Inc., Cary, NC) and Analysis of Variance (ANOVA) was conducted by the PROC GLIMMIX procedure.

\section{RESULTS}

Two hundred twenty milk samples out of 260 collected from individual ewes were scored by the CMT technique, Ewes with signs of inflamed udders had a 
mean lactation of about three months. About one fourth $(26 \%)$ of the ewes had clinical signs of mastitis.

Table 1 shows the relationship between positive and negative CMT scores and the percentages of ewes milk samples of different bacterial counts. The positive and negative samples distributed in three different bacterial count ranges namely $<3.0 \times 10^{2}, 3.0 \times 10^{2}$ to $<3.0 \times 10^{3}$ and $>3.0 \times 10^{3} \mathrm{cfu} \mathrm{mL}^{-1}$, the highest percentage of CMT positive samples (60.3) was found in the range of $3.0 \times 10^{2}$ to $<3.0 \times 10^{3}$ cfu $\mathrm{mL}^{-1}$, while the highest percentage of CMT negative samples (65.5) was found in the total bacterial count of $<3.0 \times 10^{2} \mathrm{cfu} \mathrm{mL}^{-1}$.

Bacteria identified and percentage of ewe milk samples with different CMT scores were illustrated in Table 2. This indicates the relationship between specific organisms, which mostly are the causative agent of mastitis and the respective percentage of samples with negative and positive CMT. The bacteria (Staphylococcus aureus, Streptococcus agalactiae and Streptococcus spp.) showed the highest percentages for positive CMT; the bacteria (Corynebacterium pyogenes, Corynebaterium pseudotuberculosis, Pseudomonas aeruginosa and Brucella melitensis) showed only positive CMT; while the bacteria (Pasteurella multocida and Mannheimia haemolytica) showed only negative CMT.
Table 3 shows the percentage of ewes milk samples that included in two different bacterial counts of various organisms. The total bacterial count range for different bacteria infecting ewes udder was most commonly $3.0 \times 10^{2}$ to $3.0 \times 10^{3}$ rather than $>3.0 \times 10^{3} \mathrm{cfu} \mathrm{mL}^{-1}$. The most frequent bacterial flora from different ewes were: Staphylococcus aureus, Streptococcus agalactiae, Streptococcus spp., E. Coli, coagulase-negative Staphylococci, Corynebactenium spp. and Pseudomonas aeruginose. Five other aerobic bacteria were isolated. Yeast was isolated from two samples.

Table 4 shows the result of sensitivity tests of organisms isolated bacteria to antibiotics. The in vitro susceptibility testing of bacterial isolates showed that the most effective drugs were Gentamycin and Ampicillin. The less effective drug was penicillin.

Table 5 shows analysis of variance for six antibiotics and twelve bacteria.

\subsection{Statistical Analysis}

The analysis of variance for antibiotics sensitivity shows that there are significant differences between antibiotics treatment at $(\mathrm{p} \leq 0.1)$. Meanwhile, there are no significant differences between isolated bacteria.

Table 1. The relationship between positive and negative CMT scores and the percentages of ewes milk samples of different bacterial counts

\begin{tabular}{|c|c|c|c|c|}
\hline \multirow[b]{2}{*}{ CMT score } & \multirow[b]{2}{*}{ No. of samples } & \multicolumn{3}{|c|}{ Percentage of samples within the total bacterial count range } \\
\hline & & $<3.0 \times 10^{2}$ & $3.0 \times 10^{2}$ to $<3.0 \times 10^{3}$ & $>3.0 \times 10^{3}$ \\
\hline Positive & 122 & 25.2 & 60.3 & 14.5 \\
\hline Negative & 98 & 65.5 & 29.2 & 5.3 \\
\hline
\end{tabular}

Table 2. Bacteria identified and percentage of ewes milk samples with different CMT scores

\begin{tabular}{|c|c|c|c|c|}
\hline \multirow[b]{2}{*}{ Bacterial isolates } & \multirow[b]{2}{*}{ No. of samples } & \multicolumn{3}{|c|}{ Percentage of samples within CMT scores range } \\
\hline & & No. of positive & Positive & Negative \\
\hline Staphylococcus aureus & 45 & 37 & 82.20 & 17.80 \\
\hline Streptococcus agalactiae & 40 & 32 & 80.00 & 20.00 \\
\hline Streptococcus spp. (non-groupable) & 25 & 22 & 88.00 & 12.00 \\
\hline Coagulase-negative staphylococci & 12 & 9 & 75.00 & 25.00 \\
\hline Escherichia coli & 22 & 2 & 9.10 & 90.90 \\
\hline Corynebacterium pyogenes & 8 & 8 & 100.00 & 0.00 \\
\hline Streptococcus dysagalactiae & 4 & 3 & 75.00 & 25.00 \\
\hline Yeast & 2 & 1 & 50.00 & 50.00 \\
\hline Corynebacterium pseadotuberculosis & 6 & 6 & 100.00 & 0.00 \\
\hline Pasteurella multocida & 4 & 0 & 0.00 & 100.00 \\
\hline Mannheimia haemolytica & 5 & 0 & 0.00 & 100.00 \\
\hline Pseudomonas aeruginosa & 8 & 8 & 100.00 & 0.00 \\
\hline Brucella melitensis & 3 & 3 & 100.00 & 0.00 \\
\hline
\end{tabular}


Table 3. The percentage of ewes milk samples that included in two different bacterial counts of various organisms

\begin{tabular}{lccc}
\hline & & \multicolumn{1}{c}{ Percentage of samples within bacterial count range* } \\
Bacterial species & No. of samples & $>3.0 \times 10^{2}$ to $<3.0 \times 10^{3}$ & $>3.0 \times 10^{3}$ \\
\hline Staphylococcus aureus & 42 & 80.9 & 19.1 \\
Streptococcus agalactiae & 35 & 77.1 & 22.9 \\
Streptococcus spp. (non-groupable) & 20 & 80.0 & 20.0 \\
Escherichia coli & 20 & 70.0 & 30.0 \\
Coagulase negative staphylococci & 11 & 72.7 & 27.3 \\
Crynebacterium pyogens & 8 & 62.5 & 37.5 \\
Pseudomanas aeruginosa & 8 & 50.0 & 50.0 \\
Corynebacterium pseudo tuberculosis & 5 & 80.0 & 20.0 \\
Pasteurella multocida & 4 & 50.0 & 50.0 \\
Mannheimia hemolytica & 5 & 60.0 & 40.0 \\
Yeast & 2 & 100.0 & 0.0 \\
Brucella melitensis & 2 & 100.0 & 0.0 \\
Klebsiella pneumoniae & 2 & 100.0 & 0.0 \\
Enterococcus spp. & 2 & 100.0 & 0.0 \\
\hline
\end{tabular}

Table 4. Sensitivity test for bacterial isolates against different antibiotics

\begin{tabular}{|c|c|c|c|c|c|c|c|}
\hline \multirow[b]{2}{*}{ Bacterial species } & \multirow[b]{2}{*}{ No. of Isolates } & \multicolumn{6}{|c|}{ Percentage of sensitivity to antibiotic } \\
\hline & & $\mathrm{AM}$ & GM & $\mathrm{P}$ & TE & $\mathrm{NEO}$ & SUL \\
\hline Staphylococcus aureus & 42 & 88.3 & 95.2 & 23.8 & 95.2 & 47.6 & 95.2 \\
\hline Streptococcus agalactia & 35 & 77.1 & 80.0 & 28.6 & 71.4 & 77.1 & 71.4 \\
\hline Streptococcus spp. & 20 & 100.0 & 100.0 & 25.0 & 95.0 & 75.0 & 71.4 \\
\hline Escherichia coli & 20 & 30.0 & 95.0 & 0.0 & 25.0 & 25.0 & 85.0 \\
\hline Coagulase negative steph. & 11 & 90.9 & 90.9 & 27.3 & 90.9 & 45.9 & 100.0 \\
\hline Pseudomonas aeruginosa & 8 & 0.0 & 100.0 & 0.0 & 37.5 & 75.0 & 75.0 \\
\hline Corynebacterium pyogenes & 8 & 100.0 & 62.0 & 75.0 & 75.0 & 37.5 & 75.0 \\
\hline Corynebacterium pseudotuberculosis & 5 & 100.0 & 100.0 & 0.0 & 75.0 & 40.0 & 40.0 \\
\hline Pasteurella multocida & 4 & 100.0 & 50.0 & 0.0 & 50.0 & 25.0 & 50.0 \\
\hline Mannheimia hemoltytica & 5 & 100.0 & 100.0 & 20.0 & 80.0 & 40.0 & 60.0 \\
\hline Enterococcus spp. & 2 & 100.0 & 100.0 & 0.0 & 100.0 & 50.0 & 50.0 \\
\hline Klebsiella pneumonia & 2 & 100.0 & 100.0 & 0.0 & 100.0 & 25.0 & 50.0 \\
\hline Mean & & $81.78^{\mathrm{ab}}$ & $89.43^{\mathrm{a}}$ & $16.64^{\mathrm{d}}$ & $74.58^{\mathrm{ab}}$ & $46.93^{\mathrm{c}}$ & $68.58^{\mathrm{b}}$ \\
\hline
\end{tabular}

Means followed by the same letter are not significantly different based on Fisher's Protected LSD at $\mathrm{p} \leq 0.05$.

$* \mathrm{AM}=$ Ampicillin $(10 \mu \mathrm{g}), \mathrm{GM}=$ Gentamycin $(10 \mu \mathrm{g}), \mathrm{P}=$ Penicillin $(10 \mathrm{IU}), \mathrm{TE}=$ Tetracycline $(30 \mu \mathrm{g}), \mathrm{NEO}=\mathrm{Neomycin}(30$ $\mu \mathrm{g}), \mathrm{SUL}=$ Sulfamethoxazole $(25 \mu \mathrm{g})$

Table 5. Analysis of variance for six antibiotics and twelve bacteria

\begin{tabular}{lcrrr}
\hline Source of variation & DF & SS & MSS & F ratio \\
\hline Antibiotics & 5 & 43483.55 & 8696.71 & 18.07 \\
Bacteria & 11 & 8909.92 & 809.99 & 1.68 \\
Error & 55 & 26472.23 & 481.31 & \\
Total & 71 & 78865.70 & & \\
\hline
\end{tabular}

\section{DISCUSSION}

Several studies in different parts of the world have been conducted for the assessment of the occurance of clinical and subclinical mastitis in different breeds of sheep (Al-Majali and Jawabreh, 2003; Lafi et al., 1998; Contreras et al., 2007; Gebrewahid et al., 2012). The relation among CMT, the presence of inflamed udders and the bacteriological findings indicated that ewe milk is like that of cows and camels (Djabri et al., 2002; Hawari and Al-Dabbas, 2008); it also indicated that ewes have phogocytic cells, which constitute one of the essential defences against microbial infection of the mammary glands. An increase of somatic cells in milk is a good indication of inflammation as shown in Table 2 which indicates that the majority of ewes react to 
infecting bacteria by raising the somatic cells in milk. So the CMT is a useful screening test in the detection of mastitis and may serve to segregate mammary glands infected with major pathogens in a subclinical form (Schuppel and Schwope, 1998; Clements et al., 2003; Gebrewahid et al., 2012). Table 1 and 2 indicated that bacterial infection was involved in mastitis of ewes. Higher bacterial counts were present in positive CMT than in negative ones as shows in (Table 1).

In many cases of infection with a variety of bacteria, the organisms are present at less than $3.0 \times 10^{3} \mathrm{~mL}^{-1}$ and a minority exceed this level as shows in Table 3. This may indicate that there is a limit to bacterial multiplication in ewes udder probably due to complex immune system.

Staphylococcus aureus, Streptococcus agalactiae and $E$. coli were the main aetiological agents of mastitis in ewes of the present study (Table 3). Similar results had been reported by (Lafi and Hailat, 1998; Fthenakis and Jones, 1990) While in other study the most common organisms isolated from subclinical mastitis cases were coagulase-negative Staphylococci and E. Coli (Lafi et al., 1998). The in vitro susceptibility test of the bacterial isolates indicated that the bacterial flora showed greatest resistance to penicillin, this drug are the most commonly used for domestic animals in Jordan and this may lead to an accumulation of resistant bacteria to this drug. The percentage average of resistance of Grampositive cocci to penicillin was $70.1 \%$ as shown in Table 4 .

\section{CONCLUSION}

In conclusion, the results of this study indicated that mastitis was prevalent in Awassi sheep in Jordan and the Gram-positive cocci were the dominant mastitis pathogens. Thus, good attention and management practices is require to control the occurance of the disease. The proper isolation and identification of the causative organism plays a significant rol in control of the disease. Further epidemiological studies should be conducted to determine the prevalence of the disease at regional and national levels taking in consideration using effective antibiotics therapy during lactation and at drying off; this would be essential part of such a program.

\section{REFERENCES}

Al-Majali, A.M. and S. Jawabreh, 2003. Period prevalence and etiology of subclinical mastitis in Awassi sheep in Southern Jordan. Small Rumenant Res., 47: 243-248. DOI: 10.1016/S09214488(02)00259-6
Clements, A.C., D.J. Taylor and J.L. Fitzpatrick, 2003. Evaluation of diagnostic procedures for subclinical mastitis in meat-producing sheep. J. Dairy Res., 70: 139-148. PMID: 12800867

Bergonier, D. and X. Brthelot, 2003. New advances in epizootology and control of ewe mastitis. Livest. Prod. Sci., 79: 1-16. DOI: 10.1016/S03016226(02)00145-8

Bergonier, D., R. de Cremoux, R. Rupp, G. Lagriffoul and X. Berthelot, 2003. Mastitis of dairy small ruminants. Vet. Res., 34: 689-716. DOI: 10.1051/vetres:2003030

Contreras, A., C. Luengo, A. Sanchez and J.C. Corrales, 2003. The role of intramammary pathogens in dairy goats. Livest. Prod. Sci., 79: 273-282. DOI: 10.1016/S0301-6226(02)00172-0

Contreras, A., D. Sierra, A. Sanchez, J.C. Corrales and J.C. Marco et al., 2007. Mastitis in small ruminants. Small Ruminant Res., 68: 145-153. DOI: 10.1016/j.smallrumres.2006.09.011

Corrales, J.C., A. Sanchez, C. Luengo, J.B. Povedo and A. Contreras, 2004. Effect of clinical contagious agalactiae on the bulk tank milk somatic cell count in Murciano-Granadina goat herds. J. Dairy Sci., 87: 3165-3171. DOI: $\quad 10.3168 /$ jds.S00220302(04)73451-7

Dingwell, R.T., K.E. Leslie, Y.H. Schukken, J.M. Sargeant and L.L. Timms, 2003. Evaluation of the California mastitis test to detect an intramammary infection with a major pathogen in early lactation dairy cows. Can. Vet. J., 44: 413-413. PMID: 12757133

Djabri, B., N. Bareille, F. Beaudeau and H. Seegers, 2002. Quarter milk somatic cell count in infected dairy cows: A meta-analysis. Vet. Res., 33: 335-357. DOI: 10.1051/vetres:2002021

Fthenakis, G.C. and J.E.T. Jones, 1990. The effect of experimentally induced Subclinical mastitis on milk yield of ewes and on the growth of Lambs. Br. Vet. J., 146: 43-49. DOI: 10.1016/00071935(90)90075-E

Fthenakis, G.C., 1994. Prevalence and aetiology of subclinical mastitis in ewes of Southern Greece. Small Rumm. Res., 13: 293-300. DOI: 10.1016/0921-4488(94)90078-7

Gebrewahid, T.T., B.H. Abera and H.T. Menghistu, 2012. Prevalence and etiology of subclinical mastitis in small ruminants of tigray regional state, North Ethiopia. J. Vet. World, 5: 103-109. DOI: 10.5455/vetworld.2012.103-109 
Harmon, R.J., 1994. Physiology of mastitis and factors affecting somatic cell count. J. Dairy Sci., 77: 2103- 2112. DOI: 10.3168/jds.S00220302(94)77153-8

Hawari, A.D. and F. Al-Dabbas, 2008. Prevalence and distribution of mastitis pathogens and their resistance against antimicrobial agents in dairy cows in Jordan. Am. J. Ani. Vet. Sci., 3: 36-39. DOI: 10.3844/ajavsp.2008.36.39

El-Jakee, J.K., N.E. Aref, A. Gomaa, M.D. El-Hariri and H.M. Galal et al., 2013. Emerging of coagulase negative staphylococci as a cause of mastitis in dairy animals: An environmental hazard. Int. J. Vat. Sci. Med., 1: 74-78. DOI: 10.1016/j.ijvsm.2013.05.006

Osman, K.M., T.R. Zolinkov, A. Samir and A. Orabi, 2013. Prevalence, pathogenic capability, virulence genes, biofilm formation and antibiotic resistance of Listeria in goat and sheep milk confirms need of hygienic milking conditions. Pathogens Global Health, 108: 21-29. DOI: 10.1016/j.ijvsm.2013.05.006

Lafi, S.Q., A.M. Al-Majali, M.D. Rousan and J.M. Alawneh, 1998. Epidemiological studies of clinical and subclinicel ovine mastitis in Awassi sheep in northern Jordan. J. Preventive Vet. Med., 33: $171-181$. DOI: $10.1016 / \mathrm{S} 0167-$ 5877(97)00048-2

Lafi, S.Q. and N.Q. Hailat, 1998. Incidence and antibiotic sensitivity of bacteria causing bovine and ovine clinical mastitis in Jordan. Pak. Vet. J., 18: 88-94.
Las Heras, A., L. Dominguez and J.F. FernardezGaragyzable, 1999. Prevalence and aetiological of subclinical mastitis in dairy ewes of Madrid region. Small Rumm Res., 32: 21-29. DOI: 10.1016/S09214488(98)00152-7

Quinn, P.J., M.E. Carter, B. Markey and G.R. Carter, 1994. Clinical Veterinary Microbiology. 1st Edn., Wolfe Publishing, London, ISBN-13: 978-0-72341711-8, pp: 684.

Radostitis, O.M., D.C. Blood and C.C. Gay, 1994. Veterinary Medicine. 8th Edn., Bailiere Tindall, London, pp: 614.

Sargeant, J.M., K.E. Leslie, J.E. Shirley, B.J. Pulkrabek and G.H. Lim, 2001. Sensitivity and specificity of somatic cell count and California mastitis test for identifying intramammary infection in early lactation. J. Dairy Sci., 84: 2018-2018. DOI: 10.3168/jds.S0022-0302(01)74645-0

Schuppel, H. and M. Schwope, 1998. Diagnosis of mastitis using Califomia mastitis test and measurement of electric conductivity. Archiv fur Lebensmittel Hygiene, 49: 61.

Sears, P.M., R.N. Gonzales, D.J. Wilson and H.R. Han, 1993. Procedures for mastitis diagnosis and control. Vet. Clin. North Am. Food Anim Pract., 9: 445-467. PMID: 8242451

Sharma, N., N.K. Sing and M.S.Bhadwal, 2011. Relationship of somatic cell count and mastitis: An overview. Asian-Aust. J. Anim. Sci., 24: 429-438.

Sharma, N., G.J. Rho, Y.H. Hong, T.Y. Kang and H.K. Lee et al., 2012 Bovine Mastitis: An Asian perspective. Asian J. Anim. Vet. Adv., 7: 454-476. DOI: 10.3923/ajava.2012.454.476 